\title{
Minimalizm ile İkinci El Satın Alma Niyeti Arasında C2C Platformuna Olan Güvenin Aracılık Rolü
}

\author{
Esra ÖZKAN PİR \\ Dr. Öğr. Üyesi, Erzincan Binali Yıldırım Üniversitesi \\ Assistant Professor, Erzincan Binali Yıldırım University \\ epir@erzincan.edu.tr \\ ORCID: 0000-0002-1271-7397 \\ Evrim DERİNÖZLÜ \\ Dr., Eğitmen \\ Dr., Instructor \\ evrimderinozlu@gmail.com \\ ORCID: 0000-0002-1408-4386
}

\section{Öz}

Yapılan çalışmada pazarlama biliminin en önemli konularından olan tüketime özellikle de ikinci el alışverişe etkisi olduğu düşünülerek minimalizmin tüketicilerin ikinci el satın alma niyetleri üzerindeki etkisi araştırılmıştır. Bu kapsamda ikinci el alışveriş platformunu kullanan 470 tüketiciye ulaşılmıştır. İkinci el alışverişte karar üzerinde etkisinin büyük olduğu düşünülen C2C platformlarının güvenilir olmasının öneminden dolayı, araştırmada aracı değişken güven olarak belirlenmiştir. $\mathrm{Bu}$ araştırma ile minimalizmin tüketicilerin ikinci el satın alma niyetlerine etkisi ve Türkiye'deki C2C platformlarına olan güvenin aracılık etkisi ölçümlenmiştir. Yapılan araştırma neticesinde minimalizm ile satın alma niyeti 
arasında platforma olan güvenin kısmi aracı rolü olduğu bulgusuna ulaşılmıştır.

Anahtar Kelimeler: Minimalizm, Minimalist Tüketim, İkinci El, C2C, Güven

\title{
Mediating Role of Trust in C2C Platform Between Minimalism and Intention to Buy Secondhand
}

\begin{abstract}
In the study, the effect of minimalism on consumers' second-hand purchase intentions was investigated, considering that it has an effect on consumption, which is one of the most important subjects of marketing science, especially on secondhand shopping. In this context, 470 consumers using the secondhand shopping platform were reached. Due to the importance of the reliability of $\mathrm{C} 2 \mathrm{C}$ platforms, which are thought to have a great effect on the decision in second-hand shopping, the mediating variable in the research was determined as trust. With this research, the effect of minimalism on consumers' secondhand purchase intentions and the mediating effect of trust in C2C platforms in Turkey were measured. As a result of the research, it was found that trust in the platform has a partial mediating role between minimalism and purchase intention.
\end{abstract}

Keywords: Minimalism, Minimalist Consumption, Secondhand, C2C, Trust 


\section{Giriş}

Günümüz tüketim kültürü, bireyleri her gün daha fazla satın almaya yönlendirmektedir. Aradıkları mutluluğu, huzuru, olmak istedikleri statüyü, saygınlığı ürünlerde bulduğunu düşünen tüketicilere, bunları tüketim alışkanlıklarının sağlamayacağını aktarmaya çalışan minimalizm, literatürde mimari (Ertürk, 2011), moda tasarımı (Yinelek, 2014), tüketim alışkanlıkları (Dopierala, 2017) ve reklamcılık (Margariti vd., 2017) gibi çeşitli alanlarda yapılan çalışmalarla karşımıza çıkmaktadır.

C2C platformları, gelişen teknolojisi sayesinde dijital ortamların gelişmesinin dışında bireylerin bu dijital dönüşüme ayak uydurmadaki performanslarının artmasıyla popülerleşmiş ve bugün etrafımızdaki birçok bireyin gerek ürün satmak gerek ürün almak ya da her ikisini de gerçekleştirmek ve gelir elde etmek için kullandığı uygulamalar haline gelmiştir. Bireylerin alışveriş noktasında marka tercihlerinde en etkili faktörlerden biri olan alışveriş yapılan platforma olan güven kavramıdır. C2C platformlarında bireysel satın alımlar söz konusu olduğu için güven kavramı oldukça büyük ve kritik bir öneme sahiptir. Bu sebeple bu çalışmada minimalizmin tüketicilerin ikinci el alışverişlerine etkisinde $\mathrm{C} 2 \mathrm{C}$ platformuna olan güvenin rolü araştırılmıştır.

Yapılan çalışmada minimalizm ve minimalist tüketim kavramsal olarak ele alınıp sonrasında $\mathrm{C} 2 \mathrm{C}$ iş modelinin ne olduğunu örneklerle açıklanarak C2C platformlarında ikinci el alışverişte güven unsurunun aracı etkisi araştırılmıştır. 
Minimalizmin nasıl doğduğunu aktarırken minimalizmin etkisindekiler içinde, pazarlama alanındaki en önemli olgulardan tüketimin incelendiği bu araştırma, özellikle ikinci el eşya ve C2C platformlarındaki güncel durumu aktaran ve minimalizmin etkisinin araştırıldığ 1 öncü çalışmalardan olacağı düşünülmektedir.

\section{Kavramsal Çerçeve}

\section{Minimalist Tüketim}

Minimalizm, hayatın fazlalıklarını elemenin, esas olana odaklanmanın, mutluluğu bulmanın, kendini gerçekleştirmenin aracı şeklinde tanımlanmaktadır (Millburn \& Nicodemus, 2020: 40). Minimalizm, sahip olmamayı seçmeye ve kendini materyallerle ifade etmemeye dayanmaktadır (Dopierala, 2017: 77). Ludwig Miesvan der Rohe, “Minimalizm” kavramını “Less is more" (az çoktur) sözüyle özetlemiştir. Millburn ve Nicomedeus (2020: 39) minimalizmi anlamlı bir yaşam sürdürmek için kullanılan bir araç şeklinde tanımlamaktadır. Minimalizmin kelime anlamıyla araştırmacıların yaptığı tanımlar birleştiğinde ortaya anlamlı bir yaşam için sahip olduklarımızı azaltmak, sade ve basit tasarımları tercih ederek, mantıklı seçimler yaparak satın alma davranışını gerçekleştirmek üzerine kurulu bir bakış açısı olduğu gözlemlenebilmektedir.

Minimalizmin tahmin edilenden daha eski bir tarihe sahip olması ancak bu kavram ile ilgili farkındalığın son yıllarda oluştuğu gözlemlenmektedir. Minimalizmin mimariden sanata, 
yaşam tarzından tüketim alışkanlıklarına tüm alanlarda oldukça önemli bir kavram olduğu aşikardır. Mimarlık, tasarım gibi sanatsal alanlardan sosyoloji ve pazarlama gibi sosyal alanlara “Minimalizm" diğer adıyla "Sadelik" akımının izlerine rastlanmaktadır. Pazarlama alanında da gün geçtikçe önem kazanan bu kavram çeşitli bilimsel çalışmalara konu olmuştur.

Dijital dönüşüm çağında bireylerin başta teknolojik gelişmeler olmak üzere çevresindeki tüm faktörlerden etkilenerek tüketime yöneldiği görülmekte ve yapılan araştırmalarla da bu durum desteklenmektedir (Yinanç, 2020: 824). Ancak zamanla daha sade ve basit bir yaşam tarzı ve daha az tüketime geçiş ihtiyacı gün geçtikçe artış göstermekte ve tüketim karşıtı akımlar ortaya çıkmaktadır (Taş, 2020: 42; Akbulak, 2019: 21). Minimalizm geçmişte mimari, sanat gibi alanlarda ortaya çımış olsa da bugün gündelik hayatı şekillendirmeye başladığı gözlemlenmektedir (Dă̆, 2020: 50, Şenol, 2018: 437). Minimalizm, bireylerin hayatlarında gereksiz olan şeyleri sınırlandırması ya da onlardan kurtulmasına dayanır. Ancak her birey için neyin önemli, neyin gereksiz olduğu farklılık gösterecektir (Dopierala, 2017: 68). Minimalizm insanları yeni şeylere sahip olma koşturmacasından kurtarma çabasıdır (Taş, 2020: 58).

Minimalist yaşamda önemli olan ölçülü ve dengeli olmaktır (Dopierala, 2017: 69). Minimalizm, sürekli yeni şeyler satın almaya zorlayan günümüz tüketim kültürüyle eşyalarla dolu yaşam tarzlarına bir tepki olarak oluşmuş bir yaşam tarzı olarak değerlendirilebilmektedir (Taş, 2020: 58). 
Minimalist bir birey sürekli tüketme arzusunu sonlandırma eğilimindedir. Satın aldıkları ürünlerin hayatına neler kattı̆̆ının farkında olan minimalist bireyler nelere sahip olduklarını ve onların kıymetlerini bilirler. Minimalizmi benimseyen bireyler mantıklarıyla alışveriş yapmaya gayret gösterirler.

Minimalizm, genellikle maddi ve mesleki durumu oturmuş, yaşamsal ihtiyaçlarını karşılayabilen, orta ve üst sınıfın tercih ettiği bir yaşam tarzı, bir ideolojidir (Dopierala, 2017: 76-77). Minimalizm ile bireylerin gerçek isteklerinin peşinden gidip, gerçek özgürlüğü deneyimlemeleri, yaşamın amaçlarını keşfetmeleri ve kalıcı mutluluğu bulmaları hedeflenmektedir. Minimalizm yaşam tarzında, sahip olunan şeyler ile değil hayatın kendisi ile mutluluğu yakalayabilme çabasıdır (Taş, 2020: 56). Her akımda olduğu gibi bu akımda da popüler olduğu dönemlerde geçici de olsa denemek isteyenler olacaktır. Ancak uygulaması zor olduğu için sürekli tüketimden kaçınan bireyler, çevresel faktörler ve medyanın etkisiyle akımdan kolaylıkla sıyrılabilirler. Minimalizme göre, kullanılmayan ve başkalarının işine yarabilecek eski eşyaları duygusal bağ olsa da, ihtiyacı olan birine vermek, satmak, geri dönüştürmek ya da geri dönüşüme vermek gibi seçenekler kullanılmalıdır. Bu araştırmada ikinci el ürünlerin satışının gerçekleştirildiği yeni nesil iş modeli C2C platformları incelenmiştir. Literatürde yer alan çalışmalar incelendiğinde minimalizm konusuyla ilgili genel ağırlıkta sanat, tasarım, mimarlık gibi alanlarda daha çok bilimsel çalışma 
gözlemlenmekte, işletme, ekonomi, pazarlama, marka gibi konularda daha az çalışma bulunmaktadır.

\section{C2C İş Modeli}

"Consumer to Consumer" kavramının kısaltılmış hali olan C2C tüketiciden tüketiciye satış yapma iş modelidir. C2C, son yıllarda bireylerin evden para kazanma arzusuyla en yaygin iş modellerinden biri haline gelmiştir. Anwar (2017) çalışmasında C2C iş modelini, bireylerin kendi ürettikleri veya satın alıp kullanmadıkları ya da kullanıldıkları ikinci el ürünleri satmalarını sağlayan, ödeme, lojistik, iade süreçleri gibi tüm satış sonrası hizmetleri sunan bir aracılık işlemi olarak değerlendirmektedir (Anwar, 2017; Sánchez-Torres vd, 2021: 8). Bireylerin C2C alışveriş platformlarını kullanma amacı, ürün almak ya da satmaktır. Tüketiciler bu platformları sadece ürün almak, sadece ürün satmak ya da hem almak hem satmak için kullanabilmektedirler.

Günümüzde teknolojinin ilerlemesi, tüketicilerin hayatına daha entegre bir duruma gelmesiyle kullanımın artması sonucu C2C platformlarına olan eğilimin yükseldiği gözlemlenmektedir. Üyelik sistemi ile alışveriş imkânı sunan bu platformların hem bilinirlikleri hem de kullanımı artııştır.

\section{C2C Platformlarında İkinci El Alışveriş ve Güven Unsuru}

C2C platformuna güven, C2C platformundan memnun kalmış tüketicilerin tekrar alışveriş yapması ile aralarındaki ilişkinin güçlenmesi ve duygusal bir bağ kurulması sonrası 
oluşacaktır. Müşterilerinin güvenini kazanan platformlar rakiplerine karşı üstünlük kazanırlar (Sağlam ve Sağlam, 2016: 35-36). C2C platformu üyelerine karşı güven oluşturmak da C2C platformuna karşı güven oluşturmayı etkileyen bir olgudur. Bu iki güvenin oluşması, bireylerin satın alma niyetlerini de etkileyecektir (Lu vd., 2009: 357). Güven konusu her iş kolunda sahip olunması gereken etik ilkelerin başındadır. Müşterilere söz verilen ürün ya da hizmetin söz verildiği gibi ve söz verilen zamanda teslim edilmesi güveni arttırmaktadır (Torlak, 2020: 131). Bunun yanında bu sürecin iyi yönetilmesi de platforma olan güvenin oluşturulmasında büyük önem teşkil etmektedir.

Lu vd. (2009) araştırmalarında, C2C platformu satıcı-alıcı arasında güven oluşumunu hangi faktörlerin etkilediğini ve bu güvenin $\mathrm{C} 2 \mathrm{C}$ platformuna veya satıcı üyeye olan güveni nasıl etkilediğini araştırmış ve satıcı platformlarına olan güven, alıcı üyenin satın alma niyetini olumlu yönde etkilendiği ortaya konulmuştur. Yoon ve Occeña (2015) yaptıkları araştırma ile C2C platformlarında alışveriş ile ilgili bir güven modeli geliştirilmiş ve aynı zamanda cinsiyet ve yaşın C2C alışverişlerinde güvene yönelik rolünü araştırmıştır. Sağlam ve Sağlam (2016) araştırmalarında marka güveninin satın alma niyeti üzerinde pozitif etkisi olduğunu ortaya koymuşlardır. Marka güveni tüketicilerin tekrar o markadan satın almalarına neden olmaktadır. Markalar da müşterilerini rakiplere kaptırmamak için güven oluşturmaya çalışmaktadır. SánchezTorres vd. (2021) çalışmalarında Kolombiya'da yaptıkları araştırma ile C2C platformlarının kullanımına etkisi olan 
faktörleri incelemiştir. Elde ettikleri sonuçlara göre, C2C platformlarının güven ve kalite için gerekli koşulları garanti etmesi gerektiğini göstermektedir. Zahara (2021) araştırmasıyla güven unsurunun kullanıcıların C2C platformlarındaki satın alma kararları üzerindeki olumlu ve önemli etkisini ortaya koymuştur. Karar verme durumu önemli yaşam becerilerinden birini oluşturmaktadır.

\section{Uygulama}

\section{a. Araştırma Modeli}

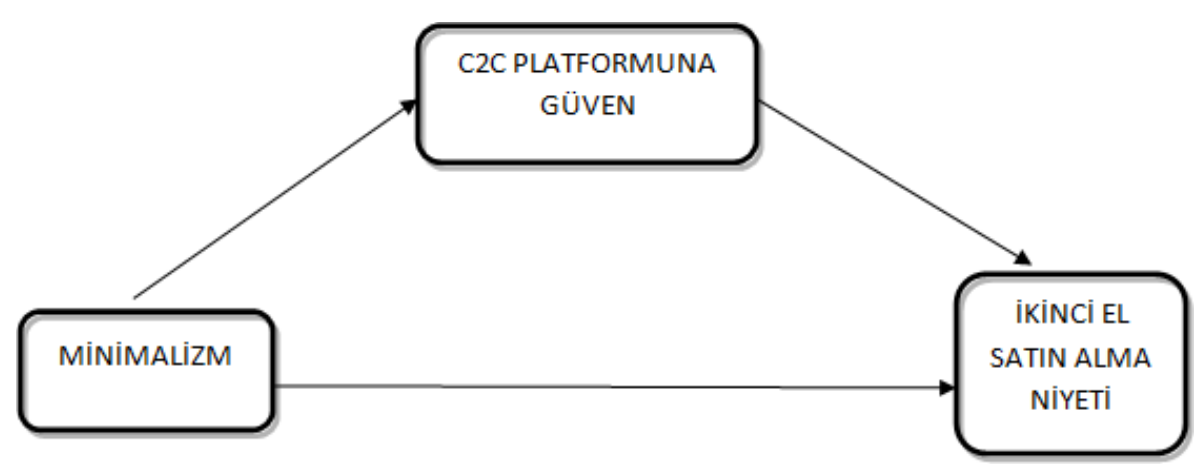

Şekil 1: Araştırma Modeli

\section{b. Araştırmanın Hipotezleri}

Bazıları için minimalizm, bazıları için sınırlı sayıda eşya demekken, bazıları için ikinci el ürünler satın almaktır (Rodriguez, 2018: 2). Minimalizm akımı bireylerin ikinci el ürünlere ilgisini artırmıştır. Özellikle geri dönüştürülmüş ürün satışı yapan markaların bu ilgide etkisi de büyüktür. Materyalizmin zıttı olduğu literatürdeki birçok kaynakta gözlenen minimalizm, bireylerin satın alma davranışını 
materyalizmin tam aksi yönde etkilemeye çalışır. Minimalist bireyler Materyalistlerin aksine düzenli olarak sahip oldukları ve satın aldıkları eşyaların miktarını azaltmaya çalışmaktadırlar. C2C platformu üyelerine karşı güven oluşturmak da C2C platformuna karşı güven oluşturmayı etkileyen bir olgudur. Bu iki güvenin oluşması, bireylerin satın alma niyetlerini de etkileyecektir ( $\mathrm{Lu} \mathrm{vd.,} \mathrm{2009:} \mathrm{357).} \mathrm{Marka}$ güveninin satın alma niyeti üzerinde pozitif etkisi olduğu ortaya konulmuştur (Sağlam ve Sağlam, 2016).

$\mathrm{Bu}$ doğrultuda araştırma kapsamında oluşturulan hipotezler şu şekildedir:

$\mathrm{H}_{1}$ : Minimalizm ile satın alma niyeti arasinda platforma olan güvenin aracı rolü vardır.

$\mathrm{H}_{2}$ : Minimalizm-sahip olunan ürün sayısı ile satın alma niyeti arasında platforma olan güvenin aracı etkisi vardır.

$\mathrm{H}_{3}$ : Minimalizm-sade görünüm ile satın alma niyeti arasında platforma olan güvenin aracı etkisi vardır.

$\mathrm{H}_{4}$ : Minimalizm-bilinçli tüketim ile satın alma niyeti arasında platforma olan güvenin aracı etkisi vardır.

\section{c. Araştırmanın Amacı}

$\mathrm{Bu}$ araştırmanın temel amacl; minimalizmin tüketicilerin ikinci el alışverişlerine etkisini ölçümleyerek tüketicilerin satın alma davranışlarında Türkiye'de kullanılan C2C platformlarına olan güvenin aracılık etkisini ortaya çıkarmaktır. 


\section{d. Araştırma Yöntemi}

Araştırmada nicel araştırma yöntemi olan anket tekniği kullanılmıştır. Araştırmanın örneklemini Türkiye genelinde ikinci el alışveriş platformlarını tercih eden 470 tüketici oluşturmaktadır. Araştırmada kolayda örnekleme yöntemi kullanılmıştır. Wilson (2020) minimalist tüketici ölçeği, Yoonve Occeña (2015) C2C e-ticaretine güven ölçeği ve Sánchez-Torres vd. (2021) satın alma niyeti ölçeği kullanılmıştır. Ölçeklerin faktör analizi yapılmış ve güvenilirliği ve geçerliliği test edilmiştir. Daha sonra, önerilen aracılık modellemesi ile test edilmiştir. Aracılık modelinin yapısal geçerliliğini belirlemek için Sobel Testi Z kullanılmıştır. Verilerin analizinde tanımlayıcı istatistikler için SPSS 25.0 paket programı, Aracılık modeli için Process Makrosu kullanılmıştır. Çalışma verileri değerlendirilirken tanımlayıcı istatistiksel metotların (Ortalama, Standart Sapma, Medyan, Frekans, Oran, Minimum, Maksimum) yanı sıra 2 grup karşılaştırmalarında Independent Sample T testi, 3 ve üzeri grup karşılaştırmalarında One-Way Anova ve ikili karşılaştırmalarında Bonferroni düzeltmesi yapılmıştır. Normal dağılım göstermeyen 3 ve üzeri grup karşılaştırmalarında ise Kruskall Wallis testi ikili karşılaştırmalarında ise Mann Whitney U testi kullanılmıştır. Anlamlılık $p<0,01$ ve $p<0,05$ düzeylerinde değerlendirilmiştir. 


\section{Bulgular}

Tablo 1: Demografik Özellikler

\begin{tabular}{|c|c|c|c|}
\hline & & $\mathrm{n}$ & $\%$ \\
\hline \multirow[t]{2}{*}{ Cinsiyet } & Kadın & 321 & 68,3 \\
\hline & Erkek & 149 & 31,7 \\
\hline \multirow[t]{2}{*}{ Medeni Durum } & Bekar & 212 & 45,1 \\
\hline & Evli & 258 & 54,9 \\
\hline \multirow[t]{4}{*}{ Yaş } & 18-25 yaş & 96 & 20,4 \\
\hline & 26-35 yaş & 151 & 32,1 \\
\hline & 36-45 yaş & 161 & 34,3 \\
\hline & 46 yaş ve üzeri & 62 & 13,2 \\
\hline \multirow[t]{5}{*}{ Ĕ̆itim Durumu } & İlköğretim & 6 & 1,3 \\
\hline & Lise & 80 & 17,0 \\
\hline & MYO / Ön lisans & 44 & 9,4 \\
\hline & Üniversite & 227 & 48,3 \\
\hline & Yüksek lisans ve üzeri & 113 & 24,0 \\
\hline \multirow[t]{4}{*}{ Gelir Düzeyi } & 3000 TL ve altr & 129 & 27,4 \\
\hline & 3001-6000 TL & 122 & 26,0 \\
\hline & 6001-9000 TL & 96 & 20,4 \\
\hline & 9001 TL ve üzeri & 123 & 26,2 \\
\hline
\end{tabular}

Yukarıda yer alan Tablo 1'de araştırmaya katılanların demografik özellikleri yer almaktadır. Katılımcıların, \%68,3’ü (n=321) kadın, \%31,7'si (n=149) erkektir. Medeni durumları incelendiğinde, \%45,1'i ( $=212)$ bekar, \%54,9'u (n=258) evlidir. Katılıcıların yaş aralıkları ise, \%20,4'ü (n=96) 18-25 yaş, \%32,1'i ( $n=151)$ 26-35 yaş, \%34,3'ü $(n=161) 36-45$ yaş ve $\% 13,2$ 'si $(n=62)$ 46 yaş ve üzeri yaş aralıklarına sahiptirler. Son mezun oldukları okul dağılımları; \%1,3 ile $(n=6)$ ilköğretim, \%17,0 ile $(n=80)$ lise, $\% 9,4$ ile (n=44) MYO / ön lisans, \%48,3 ile (n=227) lisans ve \%24,0 ile ( $n=113)$ yüksek lisans ve üzeri eğitim durumundadır. Katılımcıların gelir düzeylerinin dağılımlarının, \%27,4’ü (n=129) 3000TL ve altı, \%26,0'1 (n=122) 3001- 6000TL, \%20,4'ü $(n=96)$ 
6001-9000 TL ve \%26,2'si (n=123) 9000TL ve üzeri gelir durumundadır.

Platforma Olan Güven Ölçeği Doğrulayıcı Faktör Analizi Çalışması

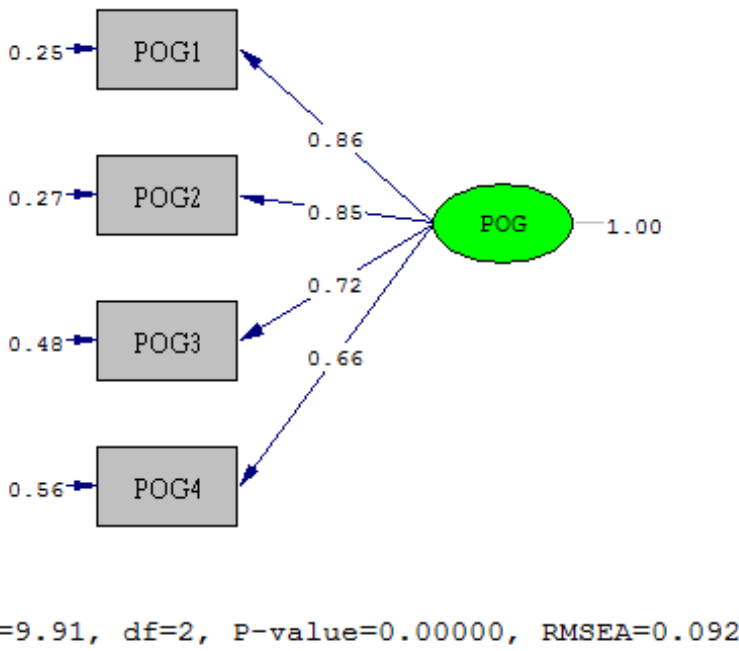

Şekil 2: Platforma Olan Güven Ölçeği / Standardize Edilmiş Model

Yapılan analiz sonucu RMSEA, NFI, NNFI, SRMR ve CFI ölçümleri uyum değerleri içerisinde yer almaktadır. Tablo 2'de gösterilmiştir. Buna göre verilerin kabul edilebilir ve iyi uyuma sahip olduğu ve doğrulayıcı faktör analizinin istatistiksel olarak anlamlı ve geçerli olduğu gözlemlenmektedir (Erkorkmaz ve ark., 2013). 
Tablo 2: Uyum İndeksleri

\begin{tabular}{llll}
\hline & İyi_Uyum & Kabul Edilebilir_Uyum & Model \\
\hline \hline$\chi 2 /$ df & $1 \leq \chi 2 /$ df $\leq 3$ & $3<\chi 2 /$ df $\leq 5$ & 4.95 \\
RMSEA & $0 \leq \mathrm{RMSEA} \leq 0.05$ & $0.05<\mathrm{RMSEA} \leq 0.10$ & 0.092 \\
NFI & $0.95 \leq \mathrm{NFI} \leq 1$ & $0.90<\mathrm{NFI}<0.95$ & 0.93 \\
NNFI & $0.95 \leq \mathrm{NFI} \leq 1$ & $0.90<\mathrm{NFI}<0.95$ & 0.94 \\
SRMR & $0 \leq \mathrm{SRMR}<0.05$ & $0.05 \leq \mathrm{SRMR}<0.10$ & 0.07 \\
CFI & $0.97 \leq \mathrm{CFI} \leq 1$ & $0.95 \leq \mathrm{CFI}<0.97$ & 0.95 \\
\hline
\end{tabular}

\section{Yakınsak ve Ayırt Edici Geçerlilik}

Yakınsak ve ayırt edici geçerlilik ile değerlendirilen ölçüm modelinin geçerliliğini araştırmaktadır. Yakınsak geçerlilik, tüm öğelerin birbirini doğrulama eğilimini ifade eder. Ylinen ve Gullkvist (2014) tarafından belirtildiği gibi, yakınsak geçerlilik, bileşik güvenilirlik (CR) ve ortalama açıklanan Varyans (AVE) incelenerek değerlendirilebilir; burada CR, yapıların tutarlılığını gösterirken AVE, yapıya göreli olarak atfedilen Varyans miktarını ölçmektedir (Azwa ve ark., 2016). Her yapı için bir bileşik güvenilirlik (C.R.) 0.6 ve üzeri olması ve (AVE) 0.5 ve üzeri olması beklenir (Bagozzi ve Yi 1988). Bununla birlikte, Fornell ve Larcker'a (1981) göre, AVE 0.5'ten küçük, ancak bileşik güvenilirlik 0,6'dan yüksek olsa bile, yapının yakınsak geçerliliği hala yeterlidir. Analizde AVE 0.5 'ten küçük değerler olsa bile bileşik güvenirlik değerleri, her yapı için 0.6'dan yüksek olması ile birlikte alındığında yakınsak geçerliliğin sağlandığı söylenebilmektedir (Pervan ve ark. 2018). Araştırmada CR ve AVE değerleri Tablo 3'te gösterilmiştir. 
Tablo 3: Platforma Olan Güven Ölçeği CR ve AVE Değerleri

\begin{tabular}{ccccc}
\hline Yap1 Maddeler & FL (>50)a & AVE(>0.5) & CR $(>0.6)^{\mathrm{a}}$ & $\boldsymbol{\alpha}(>\mathbf{0 . 7})^{\mathrm{a}}$ \\
\hline \hline 1 & 0.86 & & & \\
2 & 0.85 & 0.604 & 0.858 & 0.856 \\
3 & 0.72 & & & \\
4 & 0.66 & & & \\
\hline
\end{tabular}

\section{Minimalizm Ölçeği Doğrulayıcı Faktör Analizi Çalışması}

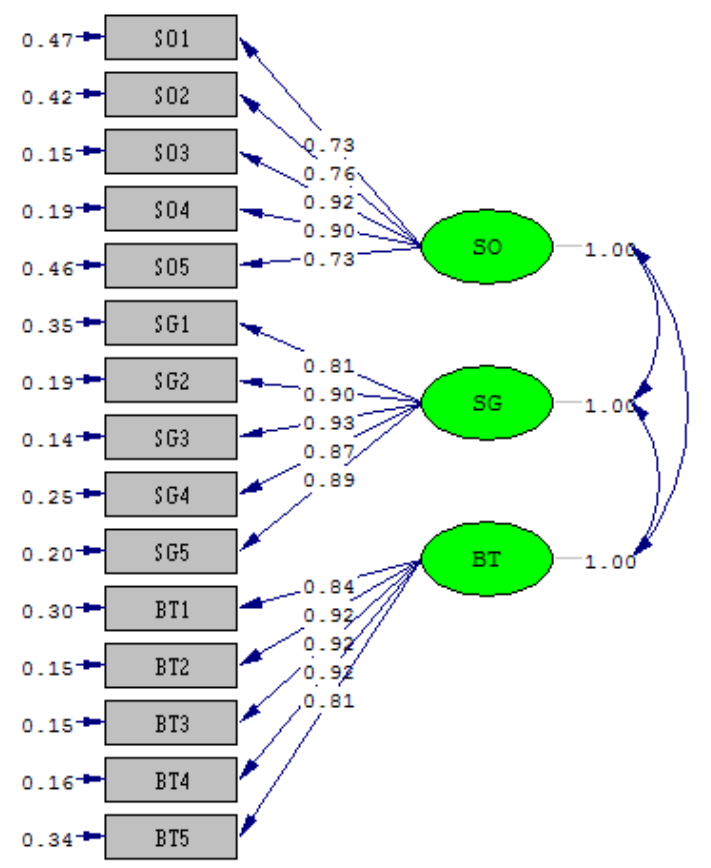

Chi-Square $=365.56, d f=87, \mathrm{P}-$ value $=0.00000$, RMSEA $=0.083$

Şekil 3: Minimalizm Ölçeği / Standardize Edilmiş Model

Yapılan analiz sonucu RMSEA, NFI, NNFI, SRMR ve CFI ölçümleri uyum değerleri içerisinde yer almaktadır. Tablo 4'te gösterilmiştir. Buna göre verilerin kabul edilebilir ve iyi uyuma sahip olduğu ve doğrulayıcı faktör analizimizin istatistiksel olarak anlamlı ve geçerli olduğunu gösterilmektedir (Erkorkmaz ve ark., 2013). 
Tablo 4: Uyum İndeksleri

\begin{tabular}{llll}
\hline & İy Uyum & Kabul Edilebilir Uyum & Model \\
\hline \hline$\chi 2$ df & $1 \leq \chi 2 / \mathrm{df} \leq 3$ & $3<\chi 2 / \mathrm{df} \leq 5$ & 4.20 \\
RMSEA & $0 \leq \mathrm{RMSEA} \leq 0.05$ & $0.05<\mathrm{RMSEA} \leq 0.10$ & 0.083 \\
$\mathrm{NFI}$ & $0.95 \leq \mathrm{NFI} \leq 1$ & $0.90<\mathrm{NFI}<0.95$ & 0.94 \\
$\mathrm{NNFI}$ & $0.95 \leq \mathrm{NFI} \leq 1$ & $0.90<\mathrm{NFI}<0.95$ & 0.92 \\
$\mathrm{SRMR}$ & $0 \leq \mathrm{SRMR}<0.05$ & $0.05 \leq \mathrm{SRMR}<0.10$ & 0.08 \\
$\mathrm{CFI}$ & $0.97 \leq \mathrm{CFI} \leq 1$ & $0.95 \leq \mathrm{CFI}<0.97$ & 0.95 \\
\hline
\end{tabular}

\section{Yakınsak ve Ayırt Edici Geçerlilik}

Yakınsak geçerlilik, tüm öğelerin birbirini doğrulama eğilimini ifade etmektedir. Her yapı için bir bileşik güvenilirlik (C.R.) 0.6 ve üzeri olması ve (AVE) 0.5 ve üzeri olması beklenir (Bagozzi ve Yi 1988). Bununla birlikte, Fornell ve Larcker'a (1981) göre, AVE 0.5'ten küçük, ancak bileşik güvenilirlik 0,6'dan yüksek olsa bile, yapının yakınsak geçerliliği hala yeterlidir. Analizde AVE 0.5'ten küçük değerler olsa bile bileşik güvenirlik değerleri, her yapı için 0.6'dan yüksek olması ile birlikte alındığında yakınsak geçerliliğin sağlandığı söylenebilmektedir (Pervan ve ark. 2018). Araştırmada CR ve AVE değerleri Tablo 5'de gösterilmiştir. 
Tablo 5: Minimalizm Ölçeği CR ve AVE Değerleri

\begin{tabular}{ccccc}
\hline Yapi Maddeler & FL $(>\mathbf{5 0})^{\mathrm{a}}$ & AVE $(>\mathbf{0 . 5})^{\mathrm{a}}$ & $\mathbf{C R}(>\mathbf{0 . 6})^{\mathrm{a}}$ & $\boldsymbol{\alpha}(>\mathbf{0 . 7})^{\mathrm{a}}$ \\
\hline \hline 1 & 0.73 & & \\
2 & 0.76 & & \\
3 & 0.92 & & \\
4 & 0.9 & & \\
5 & 0.73 & & \\
6 & 0.81 & & \\
7 & 0.9 & & \\
8 & 0.93 & & \\
9 & 0.97 & & \\
10 & 0.89 & & \\
11 & 0.84 & & \\
12 & 0.92 & \\
13 & 0.92 & \\
14 & 0.92 & & \\
15 & 0.81 & & \\
\hline
\end{tabular}

İkinci El Ürün Satın Alma Niyeti Ölçeği Doğrulayıcı Faktör

\section{Analizi Çalışması}

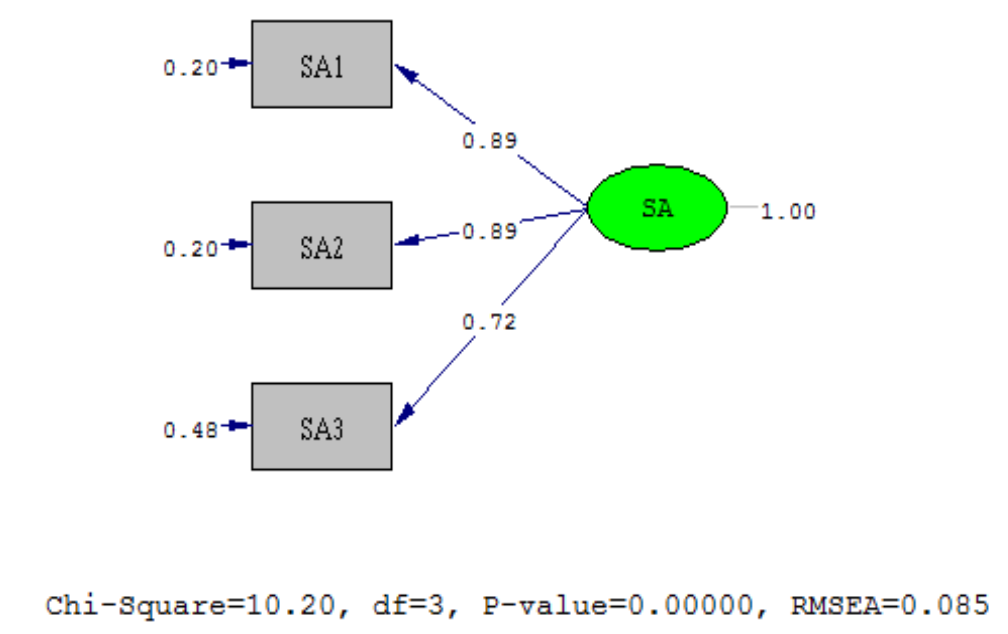

Şekil 4: İkinci El Ürün Satın Alma Niyeti Ölçeği / Standardize Edilmiş

$$
\text { Model }
$$

Yapılan analiz sonucu RMSEA, NFI, NNFI, SRMR ve CFI

ölçümleri uyum değerleri içerisinde yer almaktadır. Tablo 6’da 
gösterilmiştir. Buna göre verilerin kabul edilebilir ve iyi uyuma sahip olduğu ve doğrulayıcı faktör analizinin istatistiksel olarak anlamlı ve geçerli olduğu gösterilmektedir (Erkorkmaz ve ark., 2013).

Tablo 6: Uyum İndeksleri

\begin{tabular}{llll}
\hline & İyi Uyum & Kabul Edilebilir Uyum & Model \\
\hline \hline$\chi 2 / \mathrm{df}$ & $1 \leq \chi 2 / \mathrm{df} \leq 3$ & $3<\chi 2 / \mathrm{df} \leq 5$ & 3.40 \\
RMSEA & $0 \leq \mathrm{RMSEA} \leq 0.05$ & $0.05<\mathrm{RMSEA} \leq 0.10$ & 0.085 \\
$\mathrm{NFI}$ & $0.95 \leq \mathrm{NFI} \leq 1$ & $0.90<\mathrm{NFI}<0.95$ & 0.92 \\
$\mathrm{NNFI}$ & $0.95 \leq \mathrm{NFI} \leq 1$ & $0.90<\mathrm{NFI}<0.95$ & 0.91 \\
$\mathrm{SRMR}$ & $0 \leq \mathrm{SRMR}<0.05$ & $0.05 \leq \mathrm{SRMR}<0.10$ & 0.06 \\
$\mathrm{CFI}$ & $0.97 \leq \mathrm{CFI} \leq 1$ & $0.95 \leq \mathrm{CFI}<0.97$ & 0.95 \\
\hline
\end{tabular}

\section{Yakınsak ve Ayırt Edici Geçerlilik}

Her yapı için bir bileşik güvenilirlik (C.R.) 0.6 ve üzeri olması ve (AVE) 0.5 ve üzeri olması beklenir (Bagozzi ve Yi 1988). Bununla birlikte, Fornell ve Larcker'a (1981) göre, AVE 0.5 'ten kü çük, ancak bileşik güvenilirlik 0,6'dan yüksek olsa bile, yapının yakınsak geçerliliği hala yeterlidir. Analizde AVE 0.5 'ten küçük değerler olsa bile bileşik güvenirlik değerleri, her yapı için 0.6'dan yüksek olması ile birlikte alındığında yakınsak geçerliliğin sağlandığını söylenebilmektedir (Pervan ve ark. 2018). Çalışmada CR ve AVE değerleri Tablo 7'de gösterilmiştir. 
Tablo 7: İkinci El Ürün Satın Alma Niyeti Ölçeği CR ve AVE

Değerleri

\begin{tabular}{ccccc}
\hline Yap1 Maddeler & FL (>50) & AVE $(>\mathbf{0 . 5})^{\mathrm{a}}$ & CR $(>\mathbf{0 . 6})^{\mathrm{a}}$ & $\boldsymbol{\alpha}_{(>\mathbf{0 . 7})^{\mathrm{a}}}$ \\
\hline \hline 1 & 0.89 & & & \\
2 & 0.89 & 0.701 & 0.874 & 0.873 \\
3 & 0.72 & & & \\
\hline
\end{tabular}

Bir dağılımın normal bir dağılım gösterip göstermediğine karar vermek için çarpıklık ve basıklık değerleri dikkate alınır. $\mathrm{Bu}$ noktada basıklık ve çarpıklık değerlerinin kesme noktaları (sınırları) çarpıklık (Skewness) için mutlak değer olarak 3 ve basıklık (Kurtosis) için mutlak değer olarak 10'un üzerinde olmamalıdır (Kline, 2011). Ölçeklerin Cronbach Alpha değerlerinin 0,70 ile 0,99 olması güvenilir olduğunu göstermektedir (Tavakol ve Dennick, 2011). Çalışmada basıklık ve çarpıklık değerleri ile Cronbach Alpha değerleri belirtilen değer aralıklarında bulunmuştur. 
Tablo 8: Ölçeklerin Alt Boyut Puan Ortalamaları

\begin{tabular}{|c|c|c|c|c|c|}
\hline & Ort $\pm S S$ & $\begin{array}{l}\text { Min-Max } \\
\text { (Medyan) } \\
\end{array}$ & Çarpilık & Basıklık & Cronbach's Alpha \\
\hline $\begin{array}{l}\text { Platforma } \\
\text { Olan Güven } \\
\text { Ölçeği }\end{array}$ & $3,02 \pm 0,82$ & $1-5(3)$ & $-0,417$ & $-0,141$ & 0,856 \\
\hline $\begin{array}{l}\text { Minimalizm } \\
\text { Ölçeği }\end{array}$ & $3,92 \pm 0,76$ & $1-5(4)$ & $-1,503$ & 3,404 & 0,939 \\
\hline $\begin{array}{l}\text { Sahip Olunan } \\
\text { Ürün Sayısı } \\
\end{array}$ & $3,64 \pm 0,96$ & $1-5(3,80)$ & $-0,777$ & 0,269 & 0,905 \\
\hline Sade Görünüm & $3,96 \pm 0,95$ & $1-5(4)$ & $-1,291$ & 1,759 & 0,943 \\
\hline Bilinçli Tüketim & $4,15 \pm 0,83$ & $1-5(4)$ & $-1,743$ & 4,179 & 0,945 \\
\hline $\begin{array}{l}\text { İkinci El Ürün } \\
\text { Satın Alma } \\
\text { Niyeti }\end{array}$ & $3,01 \pm 1,00$ & $1-5(3)$ & $-0,229$ & $-0,440$ & 0,873 \\
\hline
\end{tabular}

\section{Aracılık Rolünün İncelenmesi}

Hipotez 1: Minimalizm ile satm alma niyeti arasında platforma olan güvenin aract rolü vardır.

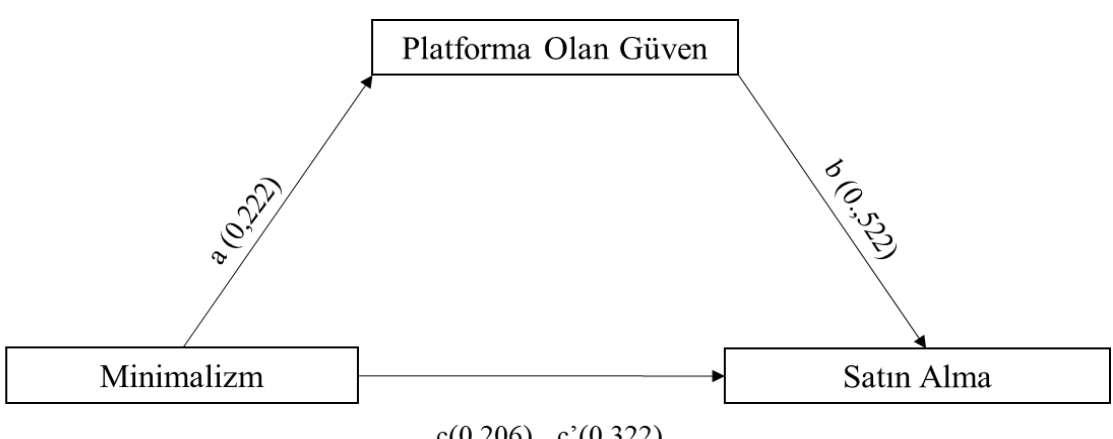

Sobel Z-score $=4,1702 \mathrm{p}=0,001$

Şekil 5: Aracılık Modeli H1

Minimalizm ile satın alma niyeti arasında platforma olan güvenin aracı rolünün olup olmadığını belirlemek için Sobel 
Testi Z kullanılmıştır. Bu model için tespit edilen Z skor (4.1702) 1,96'dan daha büyük ve anlamlı olduğu için aracı rolünün olduğu bulgusuna ulaşılmıştır. Tablo 9'da toplam etki, doğrudan etki ve dolaylı etki değerlerine bu sunulmuştur. Varsayılan hipotez kabul edilmiştir.

Tablo 9: Toplam, Doğrudan ve Dolaylı Etki Değerleri

\begin{tabular}{lccccc}
\hline & $\begin{array}{c}\text { Toplam } \\
\text { Etki }\end{array}$ & $\begin{array}{c}\text { Doğrudan } \\
\text { Etki }\end{array}$ & $\begin{array}{c}\text { Dolaylı } \\
\text { Etki }\end{array}$ & $\begin{array}{c}\text { Güven } \\
\text { Aralığı }\end{array}$ & $\begin{array}{c}\text { Aracı } \\
\text { Etki } \\
\text { Türü }\end{array}$ \\
\hline \hline $\begin{array}{l}\text { Minimalizm- } \\
\text { Platforma Olan }\end{array}$ & 0,322 & 0,206 & 0,116 & $0,054-0,187$ & Kısmi \\
Güven- Satın Alma & & & & & \\
\hline
\end{tabular}

Toplam etki ve doğrudan etki arasındaki fark dolaylı etki aracıllk rolünün büyüklüğünü göstermektedir. Tablo 9'dan anlaşılacağı gibi, aracılık rolü \%11,6 düzeyindedir.

Hipotez 2: Minimalizm-sahip olunan ürün sayısı ile satm alma niyeti arasında platforma olan güvenin aracı etkisi vardır.

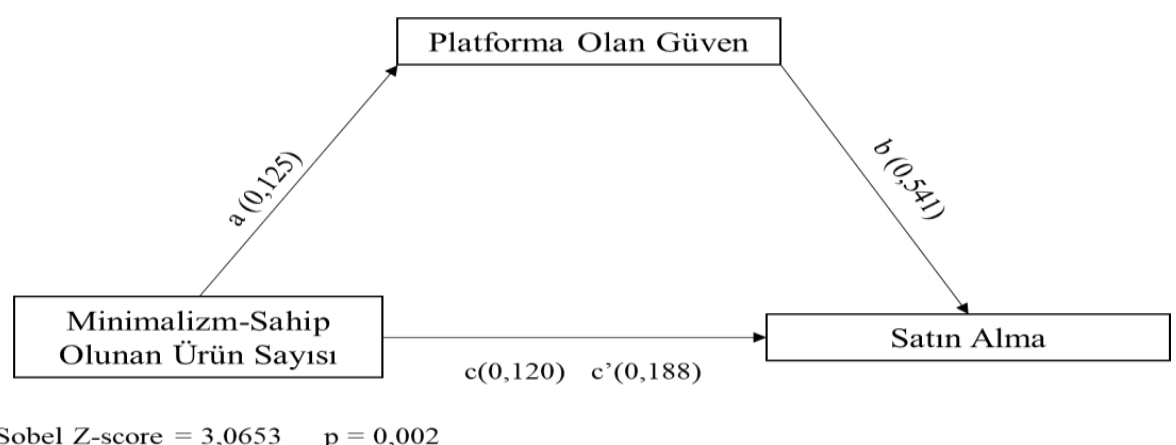

Şekil 6: Aracılık Modeli H2 
Minimalizm-sahip olunan ürün sayısı ile satın alma niyeti arasında platforma olan güvenin aracı rolünün olup olmadığını belirlemek için Sobel Testi Z kullanılmıştır. Bu model için tespit edilen Z skor (3.0653) 1,96'dan daha büyük ve anlamlı olduğu için aracı rolünün olduğu bulgusuna ulaşılmıştır. Tablo 10'da toplam etki, doğrudan etki ve dolaylı etki değerlerine bu sunulmuştur. Varsayılan hipotez kabul edilmiştir.

Tablo 10: Toplam, Doğrudan ve Dolaylı Etki Değerleri

\begin{tabular}{lccccc}
\hline & $\begin{array}{c}\text { Toplam } \\
\text { Etki }\end{array}$ & $\begin{array}{c}\text { Doğrudan } \\
\text { Etki }\end{array}$ & $\begin{array}{c}\text { Dolaylı } \\
\text { Etki }\end{array}$ & $\begin{array}{c}\text { Güven } \\
\text { Aralığı }\end{array}$ & $\begin{array}{c}\text { Aracı } \\
\text { Etki } \\
\text { Türü }\end{array}$ \\
\hline \hline $\begin{array}{l}\text { Minimalizm-Sahip } \\
\begin{array}{l}\text { Olunan Ürün } \\
\text { Sayıs- Platforma } \\
\text { Olan Güven- Satın } \\
\text { Alma }\end{array}\end{array}$ & 0,188 & 0,120 & 0,068 & $0,019-0,120$ & Kısmi \\
\hline
\end{tabular}

Toplam etki ve doğrudan etki arasındaki fark dolaylı etki aracılık rolünün büyüklüğünü gösterir. Tablo 10'dan anlaşılacağı gibi, aracılık rolü \%6,8düzeyindedir.

Hipotez 3: Minimalizm-sade görünüm ile satın alma niyeti arasında platforma olan güvenin aracı etkisi vardır.

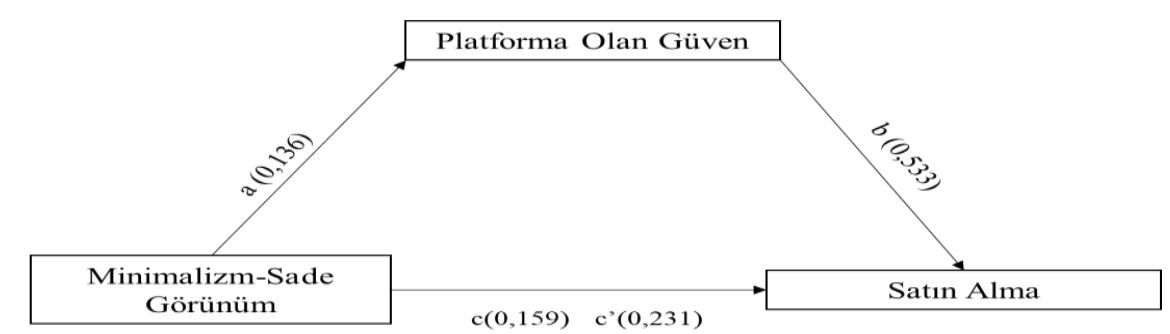

Sobel Z-score $=3,2925 \quad \mathrm{p}=0,001$

Şekil 7: Aracılık Modeli H3 
Minimalizm-sade görünüm ile satın alma niyeti arasında platforma olan güvenin aracı rolünün olup olmadığını belirlemek için Sobel Testi Z kullanılmıştır. Bu model için tespit edilen Z skor $(3,2925)$ 1,96'dan daha büyük ve anlamlı olduğu için aracı rolünün olduğu bulgusuna ulaşılmıştır. Tablo 11'de toplam etki, doğrudan etki ve dolaylı etki değerlerine bu sunulmuştur. Varsayılan hipotez kabul edilmiştir.

Tablo 11: Toplam, Doğrudan ve Dolaylı Etki Değerleri

\begin{tabular}{lccccc}
\hline & $\begin{array}{c}\text { Toplam } \\
\text { Etki }\end{array}$ & $\begin{array}{c}\text { Doğrudan } \\
\text { Etki }\end{array}$ & $\begin{array}{c}\text { Dolaylı } \\
\text { Etki }\end{array}$ & $\begin{array}{c}\text { Güven } \\
\text { Aralı̆̆ı }\end{array}$ & $\begin{array}{c}\text { Aracı } \\
\text { Etki } \\
\text { Türü }\end{array}$ \\
\hline \hline $\begin{array}{l}\text { Minimalizm-sade } \\
\text { görünüm-platforma } \\
\text { olan güven- satın }\end{array}$ & 0,231 & 0,159 & 0,072 & $0,024-0.127$ & Kısmi \\
\begin{tabular}{l} 
Alma \\
\hline
\end{tabular} & & & & & \\
\hline
\end{tabular}

Toplam etki ve doğrudan etki arasındaki fark dolaylı etki aracılık rolünün büyüklüğünü gösterir. Tablo 11'den anlaşılacağı gibi, aracılık rolü \%7,2 düzeyindedir.

Hipotez 4: Minimalizm-bilinçli tüketim ile satın alma niyeti arasında platforma olan güvenin aracı etkisi vardır.

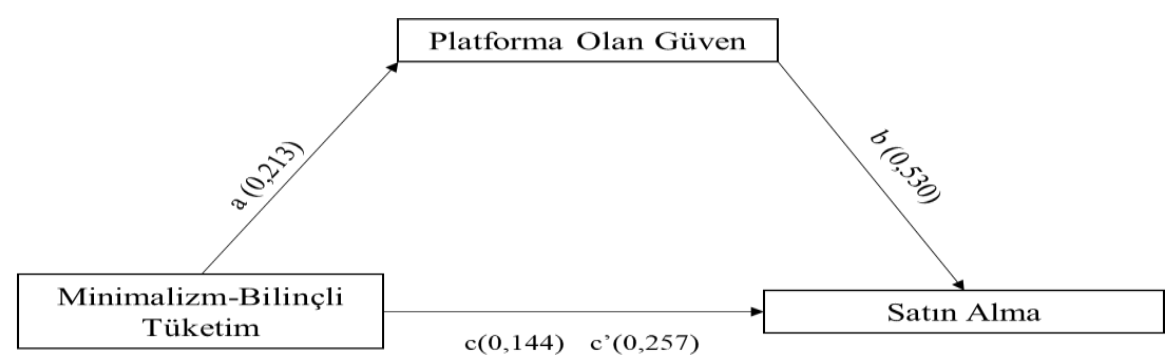

Sobel Z-score $=4,3623 \quad \mathrm{p}=0,001$

Şekil 8: Aracılık Modeli H4 
Minimalizm-bilinçli tüketim ile satın alma niyeti arasında platforma olan güvenin aracı rolünün olup olmadığını belirlemek için Sobel Testi Z kullanılmıştır. Bu model için tespit edilen Z skor $(4,3623)$ 1,96'dan daha büyük ve anlamlı olduğu için aracı rolünün olduğu bulgusuna ulaşılmıştır. Tablo 12'de toplam etki, doğrudan etki ve dolaylı etki değerlerine bu sunulmuştur. Varsayılan hipotez kabul edilmiştir.

Tablo 12: Toplam, Doğrudan ve Dolaylı Etki Değerleri

\begin{tabular}{lccccc}
\hline & $\begin{array}{c}\text { Toplam } \\
\text { Etki }\end{array}$ & $\begin{array}{c}\text { Doğrudan } \\
\text { Etki }\end{array}$ & $\begin{array}{c}\text { Dolaylı } \\
\text { Etki }\end{array}$ & $\begin{array}{c}\text { Güven } \\
\text { Aralığı }\end{array}$ & $\begin{array}{c}\text { Aracı Etki } \\
\text { Türü }\end{array}$ \\
\hline \hline $\begin{array}{l}\text { Minimalizm-Bilinçli } \\
\text { Tüketim-Platforma }\end{array}$ & 0,257 & 0,144 & 0,113 & $0,054-0,182$ & Kısmi \\
$\begin{array}{l}\text { Olan Güven-Satın } \\
\text { Alma }\end{array}$ & & & & & \\
\hline
\end{tabular}

Toplam etki ve doğrudan etki arasındaki fark dolaylı etki aracılık rolünün büyüklüğünü gösterir. Tablo 12'den anlaşılacağı gibi, aracılık rolü \%11,3düzeyindedir. 
Tablo 13: Cinsiyete Göre Platforma Olan Güven Ölçeği, Minimalizm Ölçeği ve Boyutları ve İkinci El Ürün Alma Niyeti Ölçeği Farklılık Değerlendirilmesi

\begin{tabular}{|c|c|c|c|c|c|}
\hline & \multicolumn{2}{|c|}{ Kadın $(n=321)$} & \multicolumn{2}{|c|}{ Erkek (n=149) } & \multirow[b]{2}{*}{${ }^{\mathrm{a}} \mathbf{p}$} \\
\hline & Ort $\pm S S$ & $\begin{array}{r}\text { Min-Max } \\
\text { (Medyan) } \\
\end{array}$ & Ort $\pm S S$ & $\begin{array}{r}\text { Min-Max } \\
\text { (Medyan) } \\
\end{array}$ & \\
\hline $\begin{array}{l}\text { Platforma Olan } \\
\text { Güven Ölçeği } \\
\end{array}$ & $3,06 \pm 0,81$ & $1-5(3)$ & $2,94 \pm 0,82$ & $1-5(3)$ & 0,153 \\
\hline $\begin{array}{l}\text { Sahip Olunan } \\
\text { Ürün Sayısı } \\
\end{array}$ & $3,69 \pm 0,93$ & $1-5(3,8)$ & $3,55 \pm 1,01$ & $1-5(3,8)$ & 0,149 \\
\hline Sade Görünüm & $4,03 \pm 0,9$ & $1-5(4)$ & $3,82 \pm 1,03$ & $1-5(4)$ & $0,032^{*}$ \\
\hline Bilinçli Tüketim & $4,15 \pm 0,82$ & $1-5(4)$ & $4,15 \pm 0,87$ & $1-5(4,2)$ & 0,939 \\
\hline $\begin{array}{l}\text { Minimalizm } \\
\text { Ölçeği } \\
\end{array}$ & $3,95 \pm 0,73$ & $1-5(4)$ & $3,84 \pm 0,82$ & $1-5(4)$ & 0,128 \\
\hline $\begin{array}{l}\text { İkinci El Ürün } \\
\text { Alma Niyeti } \\
\text { Ölçeği }\end{array}$ & $2,95 \pm 1$ & $1-5(3)$ & $3,14 \pm 1,01$ & $1-5(3,33)$ & 0,057 \\
\hline
\end{tabular}

andependent Sample t Testi ${ }^{*} p<0,05$

Cinsiyete göre sade görünüm boyutu istatistiksel olarak anlamlı farklılık göstermektedir $(\mathrm{p}=0,032 ; \mathrm{p}<0,05)$. Söz konusu farklılığa göre kadınların sade görünümü, erkeklere göre daha yüksek bulunmuştur. 
Tablo 14: Medeni Duruma Göre Platforma Olan Güven Ölçeği, Minimalizm Ölçeği ve Boyutları ve İkinci El Ürün Alma Niyeti Ölçeği Farklılık Değerlendirilmesi

\begin{tabular}{|c|c|c|c|c|c|}
\hline & \multicolumn{2}{|c|}{ Bekâr (n=212) } & \multicolumn{2}{|c|}{ Evli (n=258) } & \multirow[b]{2}{*}{${ }^{\mathrm{a}} \mathbf{p}$} \\
\hline & Ort $\pm S S$ & $\begin{array}{l}\text { Min-Max } \\
\text { (Medyan) }\end{array}$ & Ort $\pm S S$ & $\begin{array}{l}\text { Min-Max } \\
\text { (Medyan) } \\
\end{array}$ & \\
\hline $\begin{array}{l}\text { Platforma Olan } \\
\text { Güven Ölçeği }\end{array}$ & $2,99 \pm 0,86$ & $1-5(3)$ & $3,04 \pm 0,78$ & $1-4,75(3)$ & 0,482 \\
\hline $\begin{array}{l}\text { Sahip Olunan } \\
\text { Ürün Sayısı }\end{array}$ & $3,46 \pm 1,01$ & $1-5(3,8)$ & $3,79 \pm 0,88$ & $1-5(4)$ & $0,001^{* *}$ \\
\hline Sade Görünüm & $3,82 \pm 1,05$ & $1-5(4)$ & $4,08 \pm 0,85$ & $1-5(4)$ & $0,003^{* *}$ \\
\hline Bilinçli Tüketim & $4,1 \pm 0,95$ & $1-5(4,2)$ & $4,2 \pm 0,72$ & $1-5(4,1)$ & 0,192 \\
\hline $\begin{array}{l}\text { Minimalizm } \\
\text { Ölçeği } \\
\end{array}$ & $3,79 \pm 0,86$ & $1-5(3,97)$ & $4,02 \pm 0,66$ & $1-5(4,07)$ & $0,001^{* *}$ \\
\hline $\begin{array}{l}\text { İkinci El Ürün } \\
\text { Alma Niyeti } \\
\text { Ölçeği }\end{array}$ & $2,93 \pm 0,99$ & $1-5(3)$ & $3,08 \pm 1,01$ & $1-5(3)$ & 0,111 \\
\hline
\end{tabular}

Medeni duruma göre sahip olunan ürün sayısı boyutu istatistiksel olarak anlamlı farklılık göstermektedir $(p=0,001$; p<0,01). Söz konusu farklılığa göre bekârların sahip olduğu ürün sayısı, evlilere göre daha düşük bulunmuştur. 
Tablo 15: Yaş Duruma Göre Platforma Olan Güven Ölçeği, Minimalizm Ölçeği ve Boyutları ve İkinci El Ürün Alma Niyeti Ölçeği Farklılık Değerlendirilmesi

\begin{tabular}{|c|c|c|c|c|c|c|c|c|c|}
\hline & \multicolumn{2}{|c|}{$\begin{array}{c}18-25 \text { yaş } \\
(\mathrm{n}=96)\end{array}$} & \multicolumn{2}{|c|}{$\begin{array}{c}26-35 \text { yaş } \\
(n=151)\end{array}$} & \multicolumn{2}{|c|}{$\begin{array}{c}36-45 \text { yaş } \\
(n=161)\end{array}$} & \multicolumn{2}{|c|}{$\begin{array}{c}46 \text { yaş ve üzeri } \\
(n=62)\end{array}$} & \multirow[b]{2}{*}{$b_{p}$} \\
\hline & Ort $\pm S S$ & $\begin{array}{l}\text { Min-Max } \\
\text { (Medyan) }\end{array}$ & Ort $\pm S S$ & $\begin{array}{l}\text { Min-Max } \\
\text { (Medyan) }\end{array}$ & Ort $\pm S S$ & $\begin{array}{l}\text { Min-Max } \\
\text { (Medyan) }\end{array}$ & Ort $\pm S S$ & $\begin{array}{l}\text { Min-Max } \\
\text { (Medyan) }\end{array}$ & \\
\hline $\begin{array}{l}\text { Platforma Olan } \\
\text { Güven Ölçeği }\end{array}$ & $3,01 \pm 0,93$ & $\begin{array}{l}1-5 \\
(3)\end{array}$ & $3,04 \pm 0,8$ & $\begin{array}{l}1-5 \\
(3)\end{array}$ & $3 \pm 0,79$ & $\begin{array}{r}1-4,75 \\
(3)\end{array}$ & $3,01 \pm 0,77$ & $\begin{array}{r}1-4,25 \\
(3)\end{array}$ & 0,971 \\
\hline $\begin{array}{l}\text { Sahip Olunan } \\
\text { Ürün Sayıs }\end{array}$ & $3,24 \pm 0,97$ & $\begin{array}{r}1-5 \\
(3,4)\end{array}$ & $3,69 \pm 0,99$ & $\begin{array}{l}1-5 \\
(4)\end{array}$ & $3,84 \pm 0,83$ & $\begin{array}{l}1-5 \\
(4)\end{array}$ & $3,65 \pm 1$ & $\begin{array}{l}1-5 \\
(4)\end{array}$ & $0,001^{*}$ \\
\hline Sade Görünüm & $3,83 \pm 1,01$ & $\begin{array}{l}1-5 \\
(4)\end{array}$ & $4,03 \pm 0,95$ & $\begin{array}{l}1-5 \\
(4)\end{array}$ & $4,02 \pm 0,89$ & $\begin{array}{l}1-5 \\
(4)\end{array}$ & $3,83 \pm 0,99$ & $\begin{array}{l}1-5 \\
(4)\end{array}$ & 0,192 \\
\hline Bilinçli Tüketim & $4,02 \pm 1$ & $\begin{array}{l}1-5 \\
(4)\end{array}$ & $4,15 \pm 0,85$ & $\begin{array}{r}1-5 \\
(4,2)\end{array}$ & $4,23 \pm 0,71$ & $\begin{array}{r}1-5 \\
(4,2)\end{array}$ & $4,13 \pm 0,81$ & $\begin{array}{l}1-5 \\
(4)\end{array}$ & 0,284 \\
\hline $\begin{array}{l}\text { Minimalizm } \\
\text { Ölçeği }\end{array}$ & $3,7 \pm 0,85$ & $\begin{array}{r}1-5 \\
(3,83)\end{array}$ & $3,96 \pm 0,76$ & $\begin{array}{r}1-5 \\
(4,07)\end{array}$ & $4,03 \pm 0,67$ & $\begin{array}{r}1-5 \\
(4,07)\end{array}$ & $3,87 \pm 0,78$ & $\begin{array}{r}1,13-5 \\
(4)\end{array}$ & $0,006^{* *}$ \\
\hline $\begin{array}{l}\text { İkinci El Ürün } \\
\text { Alma Niyeti } \\
\text { Ölçeği }\end{array}$ & $2,86 \pm 0,97$ & $1-5(3)$ & $3,13 \pm 0,99$ & $\begin{array}{r}1-5 \\
(3,33)\end{array}$ & $3,03 \pm 1$ & $\begin{array}{l}1-5 \\
(3)\end{array}$ & $2,89 \pm 1,07$ & $\begin{array}{l}1-5 \\
(3)\end{array}$ & 0,148 \\
\hline
\end{tabular}

${ }^{b}$ One-Way Anova test $i *{ }^{* *} p<0,01$

Yaş durumuna göre sahip olunan ürün sayısı boyutu istatistiksel olarak anlamlı farklılık göstermektedir $(p=0,001$; $\mathrm{p}<0,01)$. Yapılan ikili karşılaştırmalara göre 18-25 yaş durumu olanların, 26-35 yaş $(p=0,001), 36-45$ yaş $(p=0,001)$ ve 46 yaş ve üzeri $(p=0,041)$ durumunda olanlardan sahip olunan ürün sayılarının düşük olması anlamlı bulunmuştur.

Yaş durumuna göre minimalizm ölçeği istatistiksel olarak anlamlı farklılık göstermektedir $(\mathrm{p}=0,001 ; \mathrm{p}<0,01)$. Yapılan ikili karşılaştırmalara göre 18-25 yaş durumu olanların, 26-35 yaş $(p=0,045)$ ve $36-45$ yaş $(p=0,004)$ durumunda olanlardan minimalizm değerlerinin düşük olması anlamlı bulunmuştur. 
Tablo 16: Eğitim Duruma Göre Platforma Olan Güven Ölçeği, Minimalizm Ölçeği ve Boyutları ve İkinci El Ürün Alma Niyeti Ölçeği Farklılık Değerlendirilmesi

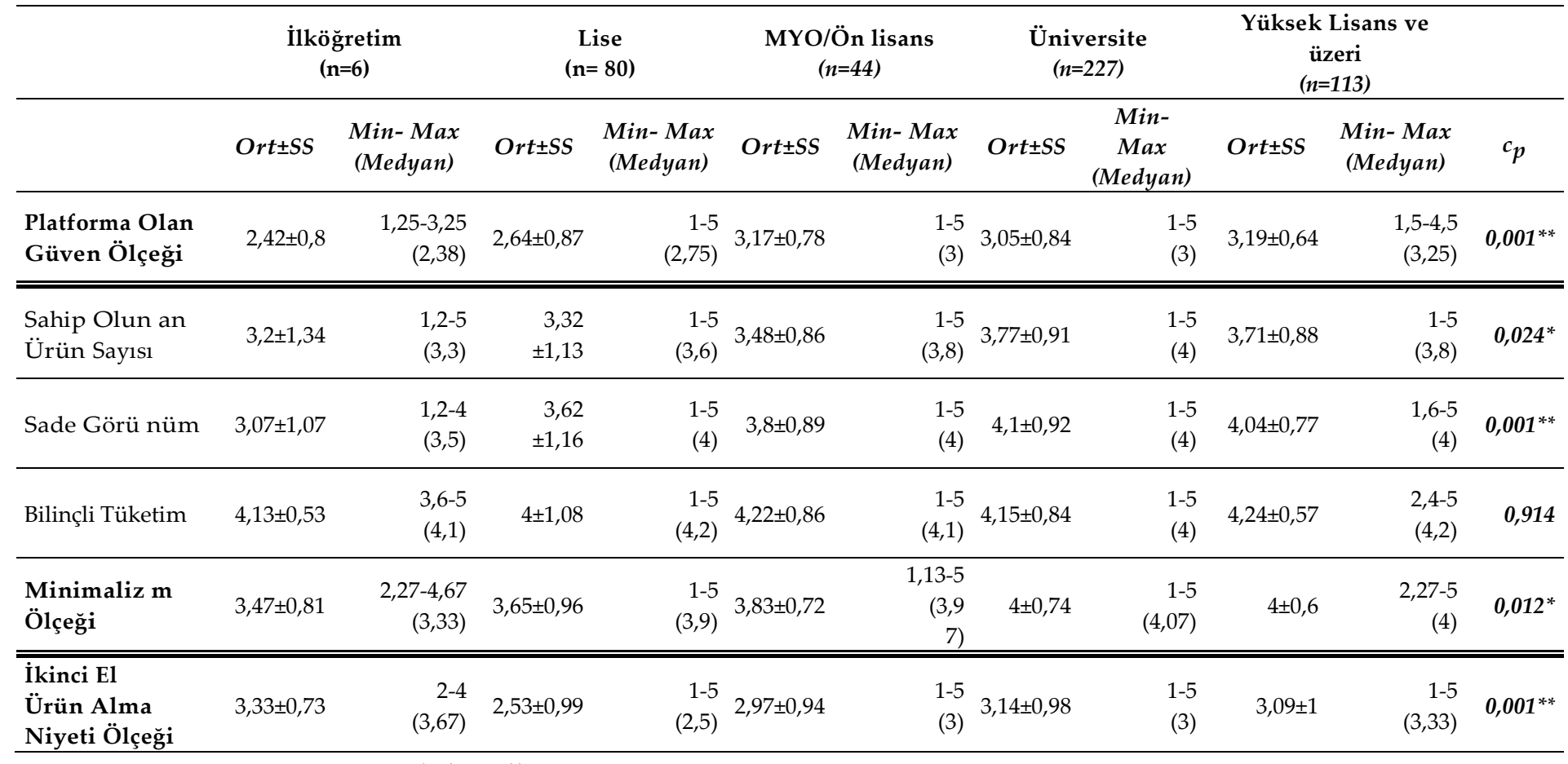

'Kruskal Wallis Test ${ }^{* *} p<0,01$

${ }^{*} p<0,05$

Eğitim durumuna göre platforma olan güven ölçeği istatistiksel olarak anlamlı farklılık göstermektedir $(p=0,001$; p<0,01). Yapılan ikili karşılaştırmalara göre ilköğretim eğitim durumunda olanların, lise $(p=0,049)$ ve yüksek lisans ve üzeri $(p=0,021)$ eğitim durumunda olanlardan platforma olan güvenlerin düşük olması anlamlı bulunmuştur. Lise eğitim durumunda olanların, MYO/Ön lisans $(p=0,001)$, Üniversite $(p=0,001)$ ve yüksek lisans ve üzeri $(p=0,021)$ eğitim durumunda olanlardan platforma olan güvenlerin düşük olması anlamlı bulunmuştur.

Eğitim durumuna göre sahip olunan ürün sayısı boyutu istatistiksel olarak anlamlı farklılık göstermektedir $(p=0,024$; 
$\mathrm{p}<0,05)$. Yapılan ikili karşılaştırmalara göre lise eğitim durumunda olanların, üniversite $(\mathrm{p}=0,004)$ ve yüksek lisans ve üzeri $(p=0,027)$ eğitim durumunda olanlardan sahip oldukları ürün sayısının düşük olması anlamlı bulunmuştur. Eğitim durumuna göre sade görünüm boyutu istatistiksel olarak anlamlı farklılık göstermektedir $(\mathrm{p}=0,001 ; \mathrm{p}<0,01)$. Yapılan ikili karşılaştırmalara göre ilköğretim eğitim durumunda olanların, MYO/Ön lisans $(p=0,030)$, üniversite $(p=0,005)$ ve yüksek lisans ve üzeri $(p=0,015)$ eğitim durumunda olanlardan sade görünümlerini düşük olması anlamlı bulunmuştur. Lise eğitim durumunda olanların, üniversite $(p=0,001)$ ve yüksek lisans ve üzeri ( $p=0,040)$ eğitim durumunda olanlardan sade görünümü düşük olması anlamlı bulunmuştur. MYO/Ön lisans eğitim durumunda olanların, üniversite $(p=0,009)$ eğitim durumunda olanlardan sade görünümü düşük çıkması anlamlı bulunmuştur.

Eğitim durumuna göre minimalizm ölçeği istatistiksel olarak anlamlı farklılık göstermektedir $(\mathrm{p}=0,012 ; \mathrm{p}<0,05)$. Yapılan ikili karşılaştırmalara göre lise eğitim durumunda olanların, üniversite $(p=0,004)$ ve yüksek lisans ve üzeri $(\mathrm{p}=0,047)$ eğitim durumunda olanlardan minimalizm ölçeğinden düşük olması anlamlı bulunmuştur.

Eğitim durumuna göre ikinci el ürün alma niyeti ölçeği istatistiksel olarak anlamlı farklılık göstermektedir $(p=0,001$; p<0,01). Yapılan ikili karşılaştırmalara göre ilköğretim eğitim durumunda olanların, lise $(p=0,030)$ eğitim durumunda olanlardan ikinci el ürün alma niyeti ölçeğinin yüksek olması 
anlamlı bulunmuştur. Lise eğitim durumunda olanların, MYO/Ön lisans ( $p=0,015)$, üniversite $(p=0,001)$ ve yüksek lisans ve üzeri $(p=0,001)$ eğitim durumunda olanlardan ikinci el ürün alma niyeti ölçeğinin düşük olması anlamlı bulunmuştur.

Tablo 17: Gelir Düzeyine Göre Platforma Olan Güven Ölçeği, Minimalizm Ölçeği ve Boyutları ve İkinci El Ürün Alma Niyeti Ölçeği Farklılık Değerlendirilmesi

\begin{tabular}{|c|c|c|c|c|c|c|c|c|c|}
\hline & \multicolumn{2}{|c|}{$\begin{array}{l}3000 \text { TL ve alt } 1 \\
(n=129)\end{array}$} & \multicolumn{2}{|c|}{$\begin{array}{c}3001-6000 \mathrm{TL} \\
(\mathrm{n}=122)\end{array}$} & \multicolumn{2}{|c|}{$\begin{array}{c}6001-9000 \mathrm{TL} \\
(n=96)\end{array}$} & \multicolumn{2}{|c|}{$\begin{array}{c}9001 \text { TL ve üzeri } \\
(n=123)\end{array}$} & \multirow[b]{2}{*}{$b_{p}$} \\
\hline & Ort $\pm S S$ & $\begin{array}{l}\text { Min-Max } \\
\text { (Medyan) }\end{array}$ & Ort $\pm S S$ & $\begin{array}{r}\text { Min-Max } \\
\text { (Medyan) }\end{array}$ & Ort $\pm S S$ & $\begin{array}{l}\text { Min-Max } \\
\text { (Medyan) }\end{array}$ & Ort $\pm S S$ & $\begin{array}{l}\text { Min-Max } \\
\text { (Med yan) }\end{array}$ & \\
\hline $\begin{array}{l}\text { Platforma Olan } \\
\text { Güven Ölçeği }\end{array}$ & $2,96 \pm 0,91$ & $\begin{array}{l}1-5 \\
(3)\end{array}$ & $3,05 \pm 0,85$ & $\begin{array}{l}1-5 \\
(3)\end{array}$ & $3,05 \pm 0,7$ & $\begin{array}{l}1-4 \\
(3)\end{array}$ & $3,02 \pm 0,76$ & $\begin{array}{c}1-4,75 \\
(3)\end{array}$ & 0,823 \\
\hline $\begin{array}{l}\text { Sahip Olunan } \\
\text { Ürün Sayısı }\end{array}$ & $3,44 \pm 1,07$ & $\begin{array}{c}1-5 \\
(3,8)\end{array}$ & $3,69 \pm 1$ & $\begin{array}{l}1-5 \\
(4)\end{array}$ & $3,66 \pm 0,85$ & $\begin{array}{l}1,6-5 \\
(3,8)\end{array}$ & $3,8 \pm 0,84$ & $\begin{array}{l}1-5 \\
(4)\end{array}$ & $0,023^{*}$ \\
\hline Sade Görünüm & $3,81 \pm 1,06$ & $\begin{array}{l}1-5 \\
(4)\end{array}$ & $3,94 \pm 1,03$ & $\begin{array}{l}1-5 \\
(4)\end{array}$ & $4,1 \pm 0,82$ & $\begin{array}{l}1-5 \\
(4)\end{array}$ & $4,04 \pm 0,82$ & $\begin{array}{l}1-5 \\
(4)\end{array}$ & 0,099 \\
\hline Bilinçli Tüketim & $4,16 \pm 0,99$ & $\begin{array}{c}1-5 \\
(4,2)\end{array}$ & $4,14 \pm 0,89$ & $\begin{array}{l}1-5 \\
(4)\end{array}$ & $4,16 \pm 0,6$ & $\begin{array}{c}2,4-5 \\
(4)\end{array}$ & $4,14 \pm 0,75$ & $\begin{array}{l}1-5 \\
(4)\end{array}$ & 0,995 \\
\hline $\begin{array}{l}\text { Minimalizm } \\
\text { Ölçeği }\end{array}$ & $3,8 \pm 0,9$ & $\begin{array}{l}1-5 \\
(4)\end{array}$ & $3,92 \pm 0,82$ & $\begin{array}{c}1-5 \\
(4,03)\end{array}$ & $3,97 \pm 0,6$ & $\begin{array}{l}2,27-5 \\
\quad(4)\end{array}$ & $3,99 \pm 0,64$ & $\begin{array}{l}1,13-5 \\
(4,07)\end{array}$ & 0,205 \\
\hline $\begin{array}{l}\text { Íkinci El Ürün } \\
\text { Alma Niyeti } \\
\text { Ölçeği }\end{array}$ & $2,89 \pm 0,98$ & $1-5(3)$ & $2,94 \pm 1,07$ & $1-5(3)$ & $3,22 \pm 0,91$ & $1-5(3,33)$ & $3,04 \pm 1,01$ & $\begin{array}{l}1-5 \\
(3)\end{array}$ & 0,085 \\
\hline
\end{tabular}

${ }^{b}$ One-Way Anova testi ${ }^{*}<<0,05^{*}$

Gelir düzeyine göre sahip olunan ürün sayısı boyutu istatistiksel olarak anlamlı farklılık göstermektedir $(p=0,001$; $p<0,01)$. Yapılan ikili karşılaştırmalara göre 3000 TL ve altı gelir düzeyine sahip olanların, 6001-9000 TL $(\mathrm{p}=0,015)$ gelir düzeyine sahip olanlardan sahip olunan ürün sayısı boyutunun düşük olması anlamlı bulunmuştur. 


\section{Tartışma ve Sonuç}

Geçmişten günümüze minimalizmin etkisinde kalan tüm bilimlerde araştırma konusu olan minimalizm, pazarlama alanı için de önemli bir konudur. Araştırmanın bulgularına göre minimalizmin bireylerin yaşamlarına ve tüketim alışkanlıklarına dolayısıyla satın alma davranışlarına etkileri gözlemlenmektedir. Araştırma sonuçlarına göre; minimalizm ile satın alma niyeti arasında platforma olan güvenin aracı rolü olduğu, minimalizm-sahip olunan ürün sayısı ile satın alma niyeti arasında platforma olan güvenin aracı etkisinin olduğu; minimalizm-sade görünüm ile satın alma niyeti arasında platforma olan güvenin aracı etkisinin olduğu ve minimalizmbilinçli tüketim ile satın alma niyeti arasında platforma olan güvenin kısmi aracı etkisinin bulunduğu ortaya çıkmıştır. Kumar vd. (2018) de minimalist pazarlama üzerinde durmuş, minimalizmi reklamlarla örneklendirmiştir. Ancak pazarlamada minimalizm tüm pazarlama karması elemanlarında uygulanabilecek bir akımdır. Akbulak (2019) inanç, sanat, mimari açısından incelediği minimalizmin tüm sanat dallarındaki yerine de değinmiştir. Bu çalışma ile minimalizmi inceleyip neden ihtiyaç duyulduğunu belirleyerek minimalizmin bir akımdan ziyade yaşam biçimi olarak tercih edilmesinin sebeplerini ortaya koymayı amaçlamıştır. Meissner (2019) minimalizmi bir yaşam tarzı olarak incelemiş ve bu kavramın bireyler tarafından çok farklı yorumlandığına değinerek anlamı ve kapsamı ile ilgili toplumca ortak noktada buluşulması konusunda yönlendirmelerde bulunmuştur. Lloyd 
(2020) ise çalışmasında minimalizmi refah ile ilişkilendirmiş, bu konuda yapılan ilk araştırma olarak minimalist yaşamı seçen bireylerle yaptığı görüşmeler sonucu çalışmasında minimalizmin refah açısından faydalarını aktarmıştır. Dă̆ (2020) minimalizmi tüketim kültürü bağlamında bir yaşam tarzı olarak incelemiştir. Yapılan araştırmada da kullanılan minimalist tüketici ölçeğini geliştiren Wilson (2020), bu alanda literatüre teorik katkılar sunmanın ötesinde tüketici minimalizmini pazarlama alanında değerlendirmiştir.

Araştırmanın demografik değişkenlerine ait sonuçları ise şu şekildedir; kadınların sade görünümü, erkeklere göre daha yüksek bulunmuştur. Kadınlar erkeklere göre ev dekorasyonu ve tasarımda sadeliğe daha fazla önem vermektedir. Minimalist yaşam tarzına olan ilgileri, ufak da olsa bunu yaşamlarına katmalarına neden olmaktadır. Bekârların sahip olduğu ürün sayısı, evlilere göre daha düşük bulunmuştur. 18-25 yaş aralığındaki kişilerin sahip oldukları ürün sayısının ve minimalizm değerlerinin diğer yaş grubundakilere göre daha düşük olduğu ortaya çıkmıştır. Bekarların ya da gençlerin, evlilere ya da yaşı 25'ten büyük olanlara göre daha az sayıda ürünle yaşamayı tercih ettikleri gözlemlenmektedir. Bunun temel nedeni gelir düşüklüğü nedeniyle zorunlu minimalistlik olabilecekken tamamen tercihleri nedeniyle minimalizmi benimsemeleri de olabilmektedir. Araştırmanın bulgularına göre tüketicilerin eğitim seviyesi yükseldikçe platforma olan güven, sahip olunan ürün sayısı ve sade görünüme olan ilgi artış göstermekte ancak ikinci el ürün satın alımı düştüğü 
gözlemlenmektedir. İkinci el ürün alışverişinin yalnızca gelir seviyesi düşük kişilerce satın alındığı olgusu her toplumda yerleşmiş bir düşünce olsa da günümüzde bireylerin ikinci el ürün satın alımları toplumun geneline yayılmıştır. Ayrıca gelir arttıkça sahip olunan ve satın alınan ürün sayısı artış göstermektedir. Bireylerin tüketim davranışları gelire bağlı olarak artış göstermekte ancak minimalizm geliri yüksek olan kişilerce de özellikle minimalist tasarımlar tercih etme açısından benimsenmektedir. Lüks markaların son yıllarda minimalist logolar, mağaza tasarımları tercih ettiği de gözlemlenebilmektedir.

Minimalist bireyler satın alma davranışını ancak ve ancak platforma güvendiklerinde sergilemektedirler. Hem platforma hem kullanıcıya güvenin oluşturulması platformun sorumluluğundadır. Platformların yönetimsel açıdan da güven unsuruna odaklanması ve kullanıcılarına karşı güven veren ifadeler, güven veren adımlar sergilemesi gerekmektedir. Bunun için ulaşılabilir olmak, gerek chatbotlarla gerekse müşteri temsilcileri ile kullanıcılara hızlı yanıt verebilmek çok önemlidir. Müşterilerini yanıltan bir platform uzun soluklu olarak faaliyetlerinde başarılı olamamaktadır. Tüketicilerin tüm soruları yanıtlanmalı, platform, alışveriş, iade benzeri süreçlerle ilgili tüm konularda belirsizlik olmamalıdır. Her şey yazılı olmalı, belgelerle tüketicilere sunulmalı, yani hizmeti somutlaştıran fiziksel kanıt dediğimiz bu unsurlar tam olmalıdır. Minimalist bireylerde esas olan az ayıda ürüne sahip olmak iken satın aldıkları ürünler ucuz olacak algısı kırılmalı, 
tüketicilerin pahalı ürünler de alabileceği unutulmamalıdır. Bu durum tüketicilerin ikinci el alışverişlerinde de yani ikinci el pahalı ürün alımlarında da C2C platformuna güvendikleri takdirde geçerlidir.

C2C platformlarının kullanıcılarının güvenlerini kazanarak yoluna devam edebilmesi onların ihtiyaç, istek ve beklentilerini doğru ve zamanında karşılamasıyla mümkün olacaktır. Öncelikli olarak müşterileriyle iletişim yöntemlerini etkin kullanmalı ve her geri dönüşü itinayla değerlendirerek çözüp sürekli iyileştirme ile süreçlerini müşteri memnuniyetini maksimize edecek seviyeye taşıması gerekmektedir. Müşterileri ile iletişimi kuvvetli olan bir platform, yoğun rekabet ortamı ile karşılaştığında dahi müşterinin güvenini kazanmış olduğu için rakiplere fark atacaktır. Teknolojik yenilikler kadar müşteriyi mutlu edecek yenilikler ve kolaylıklar ile müşterinin elde ettiği fayda artırılır, katlandığı fedakarlıklar azaltılır ise müşteri güven duyduğu platforma karşı uzun ömürlü bir bağlılık gösterecektir. Yapılacak olan bundan sonraki akademik çalışmalarda C2C platformları ve ikinci el piyasaları farklı değişkenlerle ele alınarak tüketici davranışlarını anlamlandırmak adına literatüre katkı sunacağı düşünülmektedir.

\section{Kaynakça}

Akbulak D.Z. (2019). Günümüz Tüketim Toplumunda Minimalizm ve Mikro Evler, Yüksek Lisans Tezi, Mimar Sinan Güzel Sanatlar Üniversitesi, Fen Bilimleri Enstitüsü. 
Dağ, M. (2020). Tüketim Kültürü Bă̆lamında Bir Yaşam Tarzı Olarak Minimalizm, Yüksek lisans Tezi, Necmettin Erbakan Üniversitesi, Sosyal Bilimleri Enstitüsü.

Dopierala, R. (2017). Minimalism - A New Mode of Consumption? The Central European Journal of Social Sciences and Humanity, (4), 67-83.

Erkorkmaz, Ü., Etikan, İ., Demir, O., Özdamar, K., \& Sanisoğlu, S. Y. (2013). Doğrulayıcı Faktör Analizi ve Uyum İndeksleri. Türkiye Klinikleri Journal of Medical Sciences, 33(1), 210-223.

Ertürk, M. (2011). Minimalizmin Doğuşu ve Mimaride Biçim Açısından Minimalizm Değerlendirmesi, Lisans Bitirme Tezi, İstanbul Teknik Üniversitesi, İç Mimarlık.

Kumar, S., Kumar, S., Joshi, S, SaiAvinash, B. (2018). Minimalistic Marketing: The Perfect Blend of Creativity and Simplicity, IRJMST, 9 (2), 312-321.

Lloyd, K., Pennington, W. (2020). Towards a Theory of Minimalism and Wellbeing, International Journal of Applied Positive Psychology, 5. 1-16.

Lu, Y., Zhao, L., Wang, B. (2010). From Virtual Community Members to C2C E-Commerce Buyers: Trust in Virtual Communities and its Effect on Consumers'purchase Intention, Electronic Commerce Research and Application, 9. 346-360. 10.1016/j.elerap.2009.07.003.

Margariti, K., Boutsouki, C., Leonidas, H., Zotos, Y. (2017). A Typology of Minimalism in Advertising, Advances in Advertising Research, 8,1-15.

Meissner, M. (2019). Against Accumulation: Lifestyle 
Minimalism, De-Growth and The Present Post-Ecological Condition, Journal of Cultural Economy, 12(3), 185- 200.

Millburn, J. F., Nicomedeus, R. (2020). Minimalizm: Anlamlı Bir Yaşam, Çeviren: Hülya Key, Eksik Parça Yayınları, 7. Baskı.

Rodriguez, J. (2018). The US Minimalist Movement: Radical Political Practice? Review of Radical Political Economics, 50(2), 286- 296.

Sağlam, B.Ç., Sağlam M. (2016). Marka Güveni ve Marka Bağlılığının Satın Alma Niyeti Üzerine Etkisi: Akıllı Telefon Pazarında Bir Araştırma, İşletme E Sosyal Bilimler Araştırmaları Dergisi, 5(5), 34-43.

Sánchez-Torres, J. A., Sandovala, A.V., Arroyo-Cañadab, F., Rojas- Berrioc,S.(2021). Exploring The Factors Affecting The Use of C2C in Colombia Exploración de los factores del uso del C2C en Colombia, Management Letters / Cuadernos de Gestión, 21/1,7-18.

Şenol, N.K. (2018). Minimalist Sanat Akımının Moda Üzerindeki Etkisine Genel Bir Bakış, Art - Sanat Dergisi, Pp. 437-448.

Taş, S. (2020). Tüketim Karşıtı Yaşam Tarzları: Freeganizm, Gönüllü Sadelik ve Minimalizm, Toplum ve Kültür Araştırmaları Dergisi, 6, 38-64.

Tavakol, M., Dennick, R. (2011). Making Sense of Cronbach's Alpha. International Journal of Medical Education. 2. 53-55.

Torlak, Ö. (2020). KOSGEB Girişimcilik El Kitabı, Bölüm 7: Girişimin Etik Temelleri. 
Wilson, A. (2020). The Evolving Marketplace: Essays on How Digitization and Abundance Influence Consumption, Doctoral Dissertation, Harvard University, Graduate School of Arts\&Sciences.

Yinanç, A. (2020). Kentsel Dönüşüm, Çevre ve Dijitalleşme. Uysal, H.T., Aksoy, C., \& Yılmaz, F. (Ed.), Dijital Yönetim içinde (s.1- 16). Ankara: Nobel Akademik Yayıncilık.

Yinelek, M. (2014). Minimalist Sanat Akımının Moda Tasarımcılarını Etkileme Durumu, Yüksek Lisans Tezi, Gazi Üniversitesi, Eğitim Bilimleri Enstitüsü.

Yoon, H., Occeña, L. (2015). Influencing Factors of Trustin Consumer- to-Consumer Electronic Commerce with Gender and Age, International Journal of Information Management, 35, 352-363.

Zahara, A.N., Rini, E.S., Sembiring, B.K.F. (2021). The Influence of Seller Reputation and Online Customer Reviews towards Purchase Decisions through Consumer Trust from C2C E- Commerce Platform Users in Medan, North Sumatera, Indonesia, International Journal of Research and Review, Vol.8; Issue: 2; February, pp 422-43. 